\title{
GROWTH PATTERNS IN MANUFACTURING EMPLOYMENT IN NIGERIAN CITIES
}

\author{
J. Oluwole Oyebamji*
}

\section{Introduction}

Like many developing countries, Nigeria apparently has regarded industrialization as the major panacea to the country's development problems. Although essentially an agricultural country, world experience seems to have convinced Nigeria that in order to advance like the other modern nations, the industrial (manufacturing) sector must be accorded high priority. In keeping with this belief therefore, Nigeria has continued to involve itself in the direct establishment of strategic industry and in joint ownership of numerous others. Also, in order to encourage private entrepreneurs, government has provided various forms of incentives such as protective tariffs, income tax exemptions and infrastructural development, particularly for industries oriented towards domestic needs (Schatzl 1973, pp 29-30). Among the many grand objectives of industrial development in Nigeria are the provision of employment opportunities, foreign exchange savings (particularly on consumer goods), steady promotion of capital goods industries and equitable distribution of industrial establishments.

An equitable policy is required by the political and social history of the country. With her estimated 80 million people comprising more than 250 tribal groups each apparently suspicious of the other regarding how the "national cake" would be shared, and also, with the unhappy memories of the civil wars (19671970) which represented the climax of intertribal wranglings in the country, Nigeria has had to abandon industrial policy based on the growth pole approach for one based on the balanced development approach (Oyebanji, $1982 b$ ). Thus, national policy now aims at the promotion of more even geographical spread of

\footnotetext{
*Reader in Geography, Univeristy of Ilorin (Nigeria).
}

industries and infrastructural facilities (Nigeria 1981, p. 36). As the federal government aptly puts it, "a situation where some parts of the country are experiencing rapid economic growth while other parts are lagging behind can no longer be tolerated" (Nigeria 1970 , p. $34 ; 1975$, p. 30). Hence, the federal government further argues, "consistent with the government's policy of fostering even development of all parts of the country, dispersal of industries will be actively promoted" (Nigeria 1980a, pp. 19-20).

Of the grand objectives of industrial development in Nigeria earlier outlined, that which seems to have been most difficult to achieve is equiproportionate growth. As in other parts of the world, for various reasons that are both historical and economic, manufacturing development has remained strongly urban oriented even among countries that are already at the post-industrial stage. For example, the rural share of the manufacturing labor force in the United States was only $17.5 \%$ of the national total by 1970 , while for France it was only about $15.0 \%$ by 1967 . Similarly for Canada by 1971, rural manufacturing employment was only about $15.0 \%$ of the national total (Bryant 1980, pp. 108-109). Among the developing countries, particularly in Africa, rural manufacturing employment is very negligible. In Gambia, Liberia, Gabon and Rwanda, manufacturing is totally urban, while in Nigeria rural manufacturing employment consitutes less than $3.0 \%$ of the national total, with more than $90 \%$ in the total in less than a score urban settlements (Oyebanji, 1982a).

Thus in Nigeria, as elsewhere, because of accessibility to markets and raw materials, and economies of urbanizations and large scale horizontal and vertical linkages available in urban locations, manufacturing industries have agglomerated in cities. Consequently, Lagos, 
the capital city and the main center for commerce, transportation and government (also the nation's principal port) currently has about half of the country's total manufacturing employment. Kano in the north, whose commercial reputation dates back to the pre-colonial times, ranks second, with about eleven percent of the total manufacturing employment in the country. Port Harcourt which ranks third with about nine percent is the country's second largest port and the nation's major petroleum city. Finally, Kaduna in the north which ranks fourth with about six percent of the national employment is a famous administrative center of long standing. These four cities collectively employed about $75 \%$ of the country's total manufacturing labor force by 1978 (Nigeria, 1980b). Although various infrastructural incentives such as industrial estates, roads, water and electricity are being made available to hitherto less privileged settlements, it has not been possible to easily discourage urban location of industrial activities, especially as the large majority are owned by the private sector whose principal goal is one of financial, rather than social, profitability.

\section{Research Purpose and Data Sources}

The purpose of the present study is to examine and analyze the growth patterns of manufacturing employment in Nigerian Cities. Manufacturing in the present context includes the processing and fabrication of raw materials and/or semifinished goods into new products, but excludes mining, fishing and repair services. Consequently only the industry groups ISIC (International Standard Industrial Classification) 31-39, adopting a two-digit classification, are of relevance to the present study. Since emphasis in this paper is on urban manufacturing, employment data for each industry group were calculated for all cities with at least 20,000 people by the latest population census of the country (1963), using the national Industrial Directories of 1970 and 1980 respectively (Nigeria 1970a; 1980b). Overall, about eighty cities were identified with manufacturing employment ranging from more than 126,000 for Lagos in 1978, to less than 20 employees for such cities as Potiskum, Katsina and IkoleEkiti. Altogether, the eighty manufacturing cities so identified employed about 88,000 people or $96.70 \%$ of the national total by 1968 , and about 265,000 people or $98.9 \%$ of the national manufacturing employment by 1978 . The terminal years 1968 and 1978 were used respectively because the 1970 Directory only contained information on industries established as of 1978 .

In the final analysis, all cities with at least 20,000 people but with total manufacturing employment less than 500 people were dropped. This amounted to 25 cities, and meant that only 25 cities were eventually more closely studied. Happily, these selected 25 cities altogether employed about $93.54 \%$ of the total urban manufacturing employment by 1968 , and about $97.93 \%$ of the total urban manufacturing employment by 1978 (Table 1). Thus, they were quite representative of the total picture of manufacturing characteristics in Nigerian cities.

\section{Analysis of Growth Patterns}

\section{Structural Components of Urban Manufacturing}

The structural components of manufacturing in the 25 biggest manufacturing centers can be observed in Table 2. Whereas in 1968, textile and food items dominated the urban structure, chemicals, basic metals and fabricated metals had started to gain ground by 1978 . This was very much in agreement with the national industrial objective of promoting capital good industries (Nigeria 1970b; 1975). Thus, while the producer and capital goods sectors employed only $29.32 \%$ of the total urban manufacturing labor force by 1968 , it had reached an impressively high level of $46.09 \%$ by 1978 , thus gaining nearly 17 percent points. The highest growth rates (excepting miscellaneous ISIC 39) were in fabricated metais, basic met-

\section{TABLE 1}

Nigeria: Manufacturing Employment, 1968 and 1978

\begin{tabular}{lrrrr}
\hline \multicolumn{1}{c}{ Area } & 1968 & Percent & 1978 & Percent \\
\hline Urban areas & 88,000 & 96.70 & 265,050 & 98.90 \\
25 cities & 85,125 & 93.54 & 262,452 & 97.93 \\
Other cities & 2,875 & 3.16 & 2,598 & 0.97 \\
Non-urban areas & 3,000 & 3.30 & 2,950 & 1.10 \\
Total, all areas & 91,000 & 100.00 & 268,000 & 100.00 \\
\hline
\end{tabular}

Source: Computed by author from Nigeria, Federal Republic. Industrial Directory, 1970; 1975 (Lagos: Federal Ministry of Industries). 
TABLE 2

Distribution of Manufacturing Employment in Nigerian Cities 1968-78

\begin{tabular}{|c|c|c|c|c|c|c|c|}
\hline CITY & STATE & $\begin{array}{r}1968 \\
\text { Total }\end{array}$ & $\begin{array}{c}1968 \\
\%\end{array}$ & $\begin{array}{r}1978 \\
\text { Total }\end{array}$ & $\begin{array}{c}1978 \\
\%\end{array}$ & $\begin{array}{l}\text { Change } \\
\text { Absolute }\end{array}$ & $\begin{array}{c}\text { Change } \\
\%\end{array}$ \\
\hline 1. Aba & Imo & 3,099 & 3.64 & 9,838 & 3.75 & 6,739 & 0.11 \\
\hline 2. Abeokuta & Ogun & 271 & 0.32 & 609 & 0.23 & 338 & -0.09 \\
\hline 3. Ado-Ekiti & Ondo & 121 & 0.14 & 1,846 & 0.70 & 1,728 & 0.56 \\
\hline 4. Benin & Bendel & 2,916 & 3.43 & 10,022 & 3.82 & 7,106 & 0.39 \\
\hline 5. Calabar & Cross River & 2,978 & 3.50 & 8,175 & 3.11 & 5,197 & -0.39 \\
\hline 6. Enugu & Anambra & 1,505 & 1.77 & 4,020 & 1.53 & 2,515 & -0.24 \\
\hline 7. Funtua & Kaduna & 225 & 0.26 & 617 & 0.24 & 392 & -0.02 \\
\hline 8. Gusau & Sokoto & 1,800 & 2.11 & 1,875 & 0.71 & 75 & -1.40 \\
\hline 9. Ibadan & Oyo & 3,415 & 4.01 & 3,965 & 1.51 & 550 & -2.50 \\
\hline 10. Ilorin & Kwara & 1,184 & 1.39 & 1,997 & 0.76 & 813 & -0.63 \\
\hline 11. Jos & Plateau & 797 & 0.94 & 3,330 & 1.27 & 2,533 & 0.33 \\
\hline 12. Kaduna & Kaduna & 8,950 & 10.51 & 15,241 & 5.81 & 6,291 & -4.70 \\
\hline 13. Kano & Kano & 10,762 & 12.64 & 29,167 & 11.11 & 18,405 & -1.53 \\
\hline 14. Greater Lagos & Lagos & 26,407 & 31.02 & 126,524 & 48.21 & 100,117 & 17.19 \\
\hline 15. Maiduguri & Borno & 592 & 0.70 & 608 & 0.23 & 16 & -0.47 \\
\hline 16. Ondo & Ondo & 92 & 0.10 & 634 & 0.24 & 542 & 0.14 \\
\hline 17. Onitsha & Anambra & 2,239 & 2.63 & 3,067 & 1.17 & 828 & -1.46 \\
\hline 18. Owerri & Imo & 267 & 0.31 & 854 & 0.33 & 587 & 0.01 \\
\hline 19. Port Harcourt & Rivers & 6,329 & 7.44 & 24,442 & 9.31 & 18,113 & 1.87 \\
\hline 20. Sapele & Bendel & 8,941 & 10.50 & 5,918 & 2.26 & $-3,023$ & -8.24 \\
\hline 21. Sokoto & Sokoto & 258 & 0.30 & 1,141 & 0.44 & 883 & 0.14 \\
\hline 22. Umuahia & Imo & 405 & 0.48 & 1,254 & 0.48 & 849 & 0.00 \\
\hline 23. Uyo & Cross River & 156 & 0.18 & 897 & 0.34 & 741 & 0.16 \\
\hline 24. Warri & Bendel & 162 & 0.19 & 1,731 & 0.66 & 1,569 & 0.47 \\
\hline 25. Zaria & Kaduna & 1,254 & 1.47 & 4,680 & 1.78 & 3426 & 0.31 \\
\hline
\end{tabular}

Source: Same as Table 1.

als, and chemical products which recorded growth rates of 506\%, 393\% and 306\% respectively. On the other hand, very low growth rates were recorded by some industry groups during the same period; for example food items had a growth rate of $105 \%$, paper $93 \%$, textiles $46 \%$ and wood recorded a growth rate of only $15 \%$.

\section{The Locational Aspects of Urban Manufacturing}

The salient locational aspects of urban manufacturing development in Nigeria are summarized in Table 3 . Indeed, there is a very high degree of manufacturing employment concentration in the country. By 1968 Lagos alone had almost a third of the total urban manufacturing employment in Nigeria, while Kano, which ranked second, had only about one-eighth of the total urban manufacturing labor force. So con- centrated in a few urban places was manufacturing that by 1968 only five towns (Lagos, Kano, Kaduna, Sapele and Port Harcourt) accounted for about $72 \%$ of the total manufacturing labor force in urban places in Nigeria.

Although by 1978 , every urban place except Sapele recorded absolute gains in total manufacturing employment, thereby helping the nation to fulfill one of its industrial development objectives, the spatial balance objective suffered as much greater concentrations were experienced. Lagos alone gained an additional 17.19 in percentage points, thereby accounting for almost half the total urban manufacturing employment in Nigeria by 1978 . So deplorable was the locational balance that about half the total urban industrial centers recorded percentage losses over the earlier period. Sapele suffered most, losing about 8.24 percentage points while Kaduna lost 4.70 points of its share. By 
TABLE 3

Nigeria: Structural Components of Urban Manufacturing, 1968-78

\begin{tabular}{|c|c|c|c|c|c|c|}
\hline \multirow{3}{*}{$\begin{array}{l}\text { ISIC* } \\
\text { Code }\end{array}$} & \multicolumn{5}{|c|}{ EMPLOYMENT SHARE } & \multirow{3}{*}{$\begin{array}{l}\text { GROWTH } \\
\text { Rate } \\
1968 / 78\end{array}$} \\
\hline & INDUSTRIAL & 1968 & 1968 & 1978 & 1978 & \\
\hline & Classification & Total & $\%$ & Total & $\%$ & \\
\hline 31 & Food, Beverages and Tobacco & 17,745 & 20.85 & 36,446 & 13.89 & 1.05 \\
\hline 32 & $\begin{array}{l}\text { Textiles, Wearing apparel and } \\
\text { Leather Industries }\end{array}$ & 18,372 & 21.58 & 62,889 & 24.34 & 0.46 \\
\hline 33 & $\begin{array}{l}\text { Wood and Wood products, } \\
\text { including Furniture }\end{array}$ & 13,026 & 15.30 & 14,969 & 5.70 & 0.15 \\
\hline 34 & $\begin{array}{l}\text { Paper and Paper products, Print- } \\
\text { ing and Publishing }\end{array}$ & 8,086 & 9.50 & 15,591 & 5.94 & 0.93 \\
\hline 35 & $\begin{array}{l}\text { Chemicals, Petroleum, Coal, } \\
\text { Rubber and Plastic products }\end{array}$ & 14,435 & 16.96 & 58,558 & 22.31 & 3.06 \\
\hline 36 & $\begin{array}{l}\text { Non-metallic Mineral products } \\
\text { except products of Petroleum } \\
\text { and Coal }\end{array}$ & 2,662 & 3.13 & 9,402 & 3.58 & 2.53 \\
\hline 37 & Basic Metal Industries & 1,200 & 1.41 & 5,915 & 2.26 & 3.93 \\
\hline 38 & $\begin{array}{l}\text { Fabricated Metal Products, } \\
\text { Machinery including electrical } \\
\text { and communication equipment }\end{array}$ & 9,320 & 10.95 & 56,483 & 21.52 & 5.06 \\
\hline 39 & Other Manufacturing Industries & 279 & 0.33 & 2,199 & 0.84 & 6.88 \\
\hline
\end{tabular}

*International Standard Industrial Classification

Source: Computed by author from Nigeria's Industrial Directories of 1970 and 1980 respectively

1978, Lagos towered so heavily over all the other urban industrial centers, that Port Harcourt, the second city after Lagos in positive percentage share had a mere 1.87 percentage points gain over the earlier period, while Warri, the third most fortunate city, had a percentage gain of only 0.47 percentage points over its 1968 share.

The regional variations in the distributon of manufacturing employment in Nigeria is also interesting. More than half of all the manufacturing work force is found among the southwest cities comprising Lagos, Ibadan, Abeokuta, Ondo, Ado-Ekiti, Ilorin, Benin, Sapele and Warri, which increased their share from $51.12 \%$ in 1968 to $58.39 \%$ in 1978 . On the other hand the northern manufacturing cities comprising Sokoto, Gusau, Kano, Maiduguri, Funtua, Zaria, Kaduna and Jos lost about 7.34 percentage points during the same period, thus declining from a national percentage of 28.93 in 1968 to 21.59 in 1978 . The southeast cities comprising Port Harcourt, Uyo, Aba, Umuahia, Owerri, Calabar, Onitsha and Enugu were relatively stable in their share of manufacturing employment during the period, recording $19.95 \%$ in 1968 and $20.02 \%$ in 1978 . Some of the reasons for the increasing concentration of manufacturing in the southwest include its long history of urbanization, and also the mass movement of Southerners back from the north after 1967. It is important to mention that the cities in Nigeria with population over one million, i.e., Lagos and Ibadan, are both located in the southwest region.

In order to gain much greater insight into the locational changes in urban manufacturing between 1968 and 1978, the shift and share technique has been employed specifically for the purpose of examining and accounting for differences in the industrial growth rate of the cities (Lausen 1971; Oyebanji 1982b; Stilwell 1969). In specific terms, this method attempts to account for differences in a city's industrial growth effect or the composition effect. The former is sometimes referred to as the industry mix effect while the latter is sometimes termed the differential shift effect (Oyebanji 1982b; Crowley 1978). While the industrial mix effect identifies the portion of manufacturing employment change due to the region's share of fast and slow growing industrial groups, the differential shift identifies changes in manufacturing employment due to regional industries 
TABLE 4

Shift and Share Analysis of Manufacturing Employment in Nigerian Cities, 1968-78

\begin{tabular}{|c|c|c|c|c|}
\hline City & State & Growth Effect & $\begin{array}{c}\text { Composition } \\
\text { Effect }\end{array}$ & $\begin{array}{c}\text { Total Net } \\
\text { Shift }\end{array}$ \\
\hline 1. Aba & Imo & 73 & 115 & 188 \\
\hline 2. Abeokuta & Ogun & -157 & -535 & -692 \\
\hline 3. Ado-Ekiti & Ondo & -158 & -144 & -302 \\
\hline 4. Benin & Bendel & $-4,133$ & -641 & $-4,774$ \\
\hline 5. Calabar & Cross River & -455 & $-2,807$ & $-3,262$ \\
\hline 6. Enugu & Anambra & -9 & $-1,449$ & $-1,458$ \\
\hline 7. Funtua & Kaduna & -129 & 36 & -93 \\
\hline 8. Gusau & Sokoto & 612 & $-4,284$ & $-3,672$ \\
\hline 9. Ibadan & Oyo & $-2,613$ & $-3,996$ & $-6,609$ \\
\hline 10. Ilorin & Kwara & -634 & -38 & -672 \\
\hline 11. Jos & Plateau & 15 & 79 & 94 \\
\hline 12. Kaduna & Kaduna & 1,568 & $-3,467$ & $-1,899$ \\
\hline 13. Kano & Kano & 4,168 & $-8,655$ & $-4,487$ \\
\hline 14. Greater Lagos & Lagos & 1,366 & 42,360 & 43,726 \\
\hline 15. Maiduguri & Borno & -272 & -530 & -802 \\
\hline 16. Ondo & Ondo & -110 & 277 & 167 \\
\hline 17. Onitsha & Anambra & $-1,499$ & $-1,786$ & $-3,285$ \\
\hline 18. Owerri & Imo & -263 & 53 & -210 \\
\hline 19. Port Harcourt & Rivers & 5,146 & 580 & 5,726 \\
\hline 20. Sapele & Bendel & $-5,653$ & $-15,977$ & $-21,630$ \\
\hline 21. Sokoto & Sokoto & -161 & 507 & 346 \\
\hline 22. Umuahia & Imo & -407 & 337 & -70 \\
\hline 23. Uyo & Cross River & -124 & -19 & -143 \\
\hline 24. Warri & Bendel & -16 & 833 & 817 \\
\hline 25. Zaria & Kaduna & 16 & 373 & 389 \\
\hline
\end{tabular}

Source: Same as Table 1

experiencing growth rates that are different from their national counterparts (Sternlieb and Hughes, 1975, p. 81). The summation of both the growth effect and the composition effect gives the total net shift.

These three measures of manufacturing locational changes insofar as they concern urban manufacturing development in Nigeria are shown in Table 4. Of course, within the present context, the parent region under analysis is the sum of the 25 cities; hence, the growth effect, the composition effect and the total net shift effect numbers sum to zero across the 25 cities. Only eight of the 25 cities have positive scores on the growth effect. The highest value of over 5,000 was recorded by Port Harcourt. Kano ranks second with about 4,000. Only two other cities-Kaduna and Greater Lagos-have values of more than 1,000. All the remaining cities with positive scores have extremely low values below 100 with the exception of Gusau with about 600 . The highest negative values were recorded by Sapele and Benin each with more than 400 below national average. Overall, it is evident that but for Port Harcourt, Kano, Kaduna and Lagos, the industry mix component is rather weak. The largest mix effects are experienced by Port Harcourt and Kano, at opposite ends of the country. This is due to the heavy concentrations of petroleum and chemical industries as well as non-metallic mineral products, and basic and fabricated metal industries in the former, while in the latter city, there also are large concentrations of textiles and leather industries as well as fabricated metal industries. Within the Nigerian context as elsewhere, these industries are relatively more fast growing than others. 


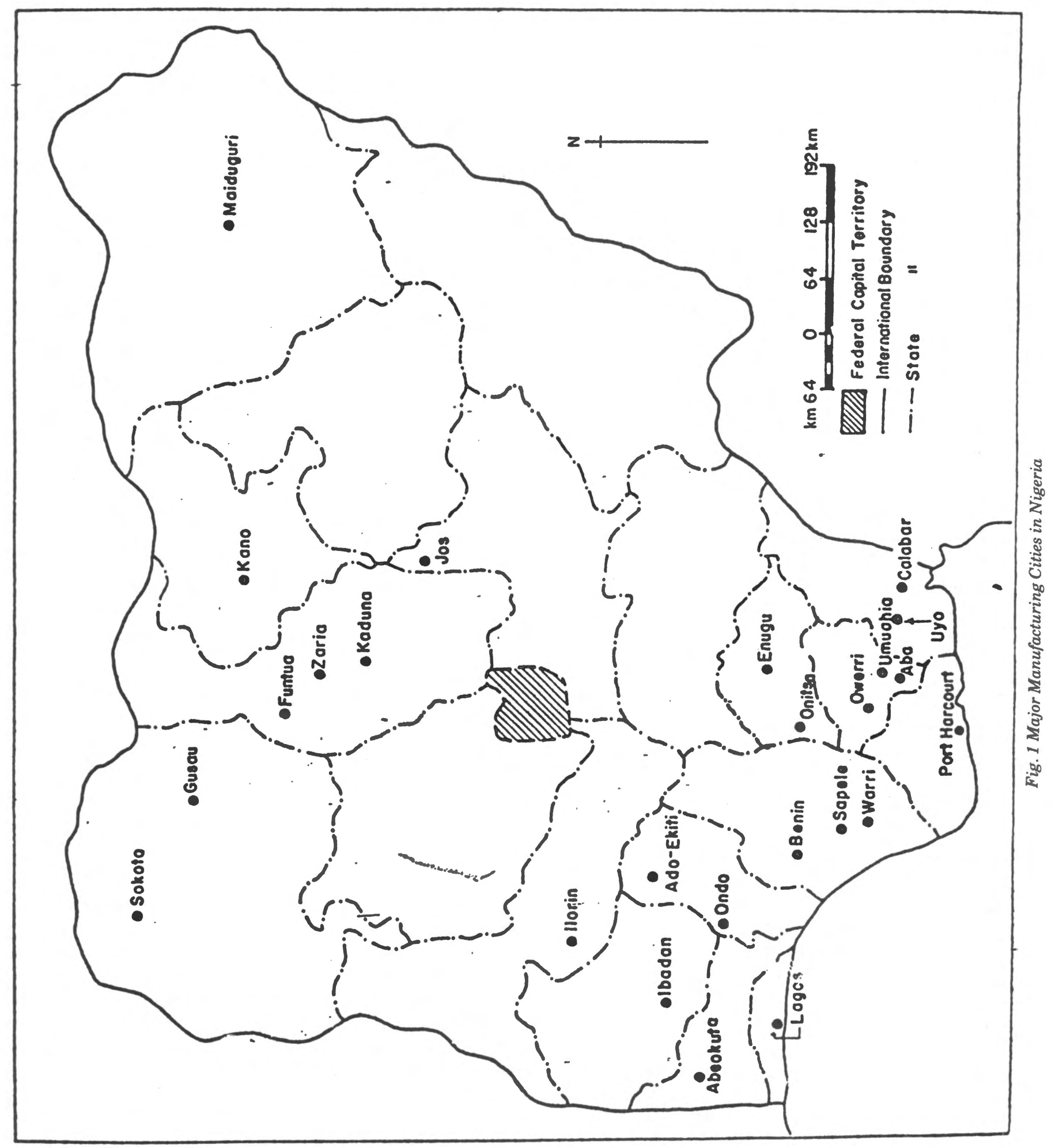


The pattern of scores on the composition effect is also not encouraging. As many as fourteen of the 25 cities had negative composition effects between 1968 and 1978. The most affected urban centers include Sapele, Kaduna, Ibadan, Gusau, Calabar, Enugu, Onitsha and a few others. Apparently, while the great majority of cities were experiencing negative composition effects, Lagos had an extremely domineering positive value. Although overall eleven cities experienced positive composition effects in the study period, the benefits were marginal for the great majority. When we add the scores on both the growth effect and the composition effect together to derive the total net shift effect, only eight urban centers experience positive total net shifts. They are Lagos, Port Harcourt, Warri, Zaria, Sokoto, Ondo, Aba and Jos. It is also important to point out that only five cities-Aba, Jos, Lagos, Port Harcourt and Zaria-experienced both positive growth and composition effects. Also, while the growth effect is dominant in eight cities, the composition effect is dominant in only eleven.

\section{Conclusions}

The results of the present study have significant ramifications for Nigeria's national, urban and regional development. The employment generation objective was quite successful in Nigerian cities as witnessed by additional employment of over 177,000 people within the ten-year study period in the 25 cities. This represented a growth rate of more than $306 \%$ for these cities. Also, the structural growth objective achieved some reasonable level of success between 1968 and 1978. Recalling that the major structural growth objective in the first national development plan of 1962-68 was to promote consumer goods such as food, beverages, tobacco, textiles, wood and wood products, and paper and print (Teriba and Kayode 1977, p. 27), that these groups of industries contributed about $70 \%$ to urban manufacturing employment was in order. Similarly, recalling the fact that the major structural growth objectives of the second and third national development plans of 1970-75 and 1976-80 respectively called for a shift in emphasis towards the capital and producer goods sectors (Oyebanji, $1982 \mathrm{~b}$ ), the 25 Nigerian cities under study very successfully reduced the percentage share of the consumer goods sector to about $54 \%$ while increasing that of the producer and capital goods industries from about 29\% in 1968 to about $46 \%$ in 1978 , thus helping towards the nation's fulfillment of the self-reliance goal.

From the regionally balanced development points of view, however, the Nigerian cities must start to take stock. For reasons already identified, Lagos, the federal capital and the hub of transportations and commerce has more than a fair share of the country's manufacturing work force; hence Lagos increased its share of urban manufacturing employment from about one-third by 1968 to about half of the national urban total by 1978 . Moreover, as the results of the shift-share analysis have shown, the distribution of the growth effect and composition effect are not encouraging as many cities recorded negative scores, even in both.

Obviously, corrective measures are needed to improve both the growth effect and the composition effect of manufacturing employment in Nigerian cities and these could be done through greater diversification and the attraction of new propulsive industries. Furthermore, given the greater development of medium sized plants in medium sized cities (Kipnis 1977, pp. 295-302), it would be desirable to divert industrial development attention from the larger cities with the bigger plants to the development of medium sized plants in medium sized cities. The apparent failure of the federal government's industrial incentives sufficient to attract private entrepreneurs to move out of the existing towns demands alternative lines of action, such as levying special taxes on new industries moving into such cities like Lagos and granting special tax concessions to those locating in less privileged places. Special marketing assistance could also be given to those industries now locating outside the traditional market centers like Lagos, Kano or Port Harcourt. Besides, government loans to industrialists could be made much more biased in favor of rural locations.

\section{REFERENCES}

Bryant, C. R. (1980). "Manufacturing in Rural Development" in Walker, D. F. (ed). Planning Industrial Development, John Wiley, New York, pp. 99-128.

Crowley, R. W. (1978). "Labor Force Growth and Specialization in Canadian Cities," in Bourne, L. S. and Simmons, J. W. (eds) Systems of Cities, Oxford University Press, New York, pp. 207-219.

Kipnis, B. A. (1977). "The Impact of Factory Size on Urban Growth and Development," Economic Geography, vol. 53, pp 205-302. 
Lasuen, J. R. (1971). "Venezuela: an Industrial Shift-Share Analysis, 1941-1961," Regional and Urban Economics, Vol. 1, pp. 153-200.

Nigeria, Federal Republic (1970a). Industrial Directory, Federal Ministry of Industries, Lagos.

Nigeria, Federal Republic (1970b). Second National Development Plan, 1970-1974, Government Printer, Lagos.

Nigeria, Federal Republic (1975). Third National Development Plan, 1975-80, Government Printer, Lagos.

Nigeria, Federal Republic (1980a). Nigerian Industrial Policy and Strategy: Guidelines to Investors, (Lagos: Govt. Printer).

Nigeria, Federal Republic (1980b). Industrial Directory, 8th Edition, Federal Ministry of Industries, Lagos.

Nigeria, Federal Republic (1981). Outline of the Fourth National Development Plan 1981-85, (Lagos: Federal
Ministry of Planning).

Oyebanji, J. O. (1982a). "The Dilemma of Rural Manufacturing in a Developing Country," Geoforum (forthcoming).

Oyebanji, J. O. (1982b). "Regional Shifts in Nigerian Manufacturing," Urban Studies, Vol. 19, No. 4.

Schatzl, L. (1973). Industrialization in Nigeria: A Spatial Analysis, Weltforum Verlag, Munchen.

Sternlieb, G. and Hughes, J. W. eds., (1975), Post Industrial America: Metropolitan Decline and Inter-Regional Job Shifts, New Brunswick: Rutgers-The State University of New Jersey.

Stilwell, F. J. (1969). "Regional Growth and Structural Adaptation," Urban Studies, Vol. 6, pp. 162-178.

Teriba, O. and Kayode, M. O., eds., (1977) Industrial Development in Nigeria, Ibadan University Press, Ibadan. 